\title{
FALLACIES IN THE STUDY OF EARLY ISRAEL: AN ONOMASTIC PERSPECTIVE
}

\author{
Richard S. Hess
}

\section{Summary}

This study considers the question of the origin of Israel and the interpretation of archaeological evidence for Palestinian hill country culture during the transition from the Late Bronze Age to the Early Iron Age. While new research has enhanced our understanding of the period, it is important to maintain methodological controls in certain areas. This includes the careful evaluation of archaeological and textual evidence without a preconceived bias which automatically assigns a priority to the material culture. There is also evidence for non-indigenous peoples in Palestine at this time. This balances assumptions that Israelites must have been 'Canaanites' with their origins entirely within Palestine. Evidence relating to these issues is discussed.

\section{Introduction}

The purpose of this paper is to examine some assumptions about the study of early Israel and to consider whether or not fallacies might be found in them. For a fallacy to exist in historical study there must be both empirical data and interpretation of that data. A fallacy can exist at the level of the data, where it is overlooked or interpreted in a way inconsistent with other data. It might also exist at the level of the interpretation in which the conclusions drawn are illogical or inadequate in the light of the data. This paper will be concerned to examine fallacies in the identification and interpretation of data.

The term 'early Israel' refers to the period described in the Bible as occurring before the time of the United Monarchy, i.e., that of the Judges and especially that of Joshua when Israel 
first entered into the land which it was to occupy. In archaeological terms, I choose to date the time described here to two periods. The first is the Late Bronze Age, between 1550 and 1200 B.C. The second includes the Early Iron Age, the 12th and 11th centuries B.C.

This essay examines the study of ancient Israel from the perspective of recent research. It is concerned with the relevant archaeological work, where archaeology is defined as the study of the material culture. The essay is also concerned with the biblical and especially with the epigraphic sources.

Fallacies appear when interpretations multiply. The number of studies on the subject of early Israel has increased in recent years. This increase has been stimulated by three factors, the appearance of new archaeological evidence, new ecological evidence, and new theories and models of explanation. Of all the recent archaeological evidence, that of the surveys is the most important. West of the Jordan Valley as well as East of it, these surveys are providing information concerning shifts in settlement patterns. ${ }^{1}$ The major change in the hill country of Palestine which took place in the 12th century has been identified with the appearance of Israel in this region.

The new ecological evidence is found especially in the observation of a period of drought in the eastern Mediterranean and in the Middle East during the latter part of the 2 nd millennium. ${ }^{2}$ This became acute in the 13th or 12th

${ }^{1} \mathrm{~A}$ summary of those west of the Jordan is available in I. Finkelstein, The Archaeology of the Israelite Settlement (Jerusalem: Israel Exploration Society, 1988). For those of the region of Moab, $c f$. J.M. Miller (ed.), Archaeological Survey of the Kerak Plateau (ASOR Archaeological Reports 1; Atlanta: Scholars, 1991).

${ }^{2}$ Bibliography can be found in T.L. Thompson, Early History of the Israelite People from the Written and Archaeological Sources (Studies in the History of the Ancient Near East 4; Leiden: Brill, 1992) 216-219. See especially J.L. Bintliff, 'Climatic Change, Archaeology, and Quaternary Science in the Eastern Mediterranean Region', in A.F. Harding (ed.),Climatic Change in Later Pre-History (Edinburgh: Edinburgh UP, 1982) 143-161; J.A. Brinkman, 'Settlement Surveys and Documentary Evidence: Regional Variation and Secular Trend in Mesopotamian Demography', JNES 43 (1984) 169-180; R. Carpenter, Discontinuity in Greek Civilization (Cambridge: CUP, 1966); F.R. 
centuries and remained so until the 10th century. This information has proved especially valuable in understanding the motivation for the movements of peoples such as those who attacked Egypt. It also provides one explanation for the disappearance of empires such as the Hittites, and of city states such as Ugarit. Finally, it may explain the decline of Egyptian influence in Palestine during the 12th century.

Studies of the period of early Israel have also been stimulated by the emergence of new theories and explanatory models. Foremost among these is the French annales approach which has led to an emphasis upon the whole population rather than leaders. It has also encouraged research into times of peace and the village life of most of the population, rather than a focus upon wars and large fortified cities. ${ }^{3}$ This approach identifies the long-term adaptations which people characteristically make in adjusting to their environment and the slow processes which affect most people. In this context change is either only apparent and cyclical or slow and so stretching over centuries. As can be appreciated, such an anthropological model fits in well with the new archaeological and ecological sources for evidence.

All of these factors have led to new and creative interpretations of the period of early Israel. While the models used have necessarily been heuristic, due to the lack of evidence in so many areas, such approaches sometimes fail to account for all the evidence which is known. Further, assumptions on which the models are based can become generalisations which

Dupont, The Late History of Ugarit, Ph.D. dissertation, Hebrew Union College (Ann Arbor: University Microfilms, 1987); J. Neumann and S. Parpola, 'Climatic Change and Eleventh-Tenth-Century Eclipse of Assyria and Babylonia', JNES 46 (1987) 161-182; W.H. Stiebing, Jr., 'The End of the Mycenaean Age', BA 43 (1980) 7-21; idem, Out of the Desert? Archaeology and the Exodus/Conquest Narratives (Buffalo, NY: Prometheus, 1989).

${ }^{3} C f$. L.E. Stager, 'The Archaeology of the Family in Ancient Israel', BASOR 260 (1985) 1-35; A.B. Knapp, Society and Polity at Bronze Age Pella: An annales Perspective (Sheffield: Sheffield Academic Press, 1993). The major study which exemplifies this approach is F. Braudel, The Mediterranean and the Mediterranean World in the Age of Philip II, 2 volumes (New York: Harper \& Row, 1972). 
then may be applied indiscriminately without consideration of their implications with respect to other evidence.

Two fallacies will be considered here: the priority of archaeological evidence over textual evidence in the reconstruction of history, and the equation of Israelite and Canaanite in terms of culture, religion and especially place of origin. These assumptions have become significant features of the interpretative landscape. Therefore, it is of value to consider their adequacy.

\section{Fallacies}

\section{Archaeological or Textual Priority of Evidence?}

With the growth of non-textual evidence and the development of models of interpretation based upon this evidence, the result has been a shift in the weight and consideration given to the written sources. This natural movement has unfortunately led to the articulation of anthropological and sociological models that give little or no consideration to the textual evidence of the Hebrew Bible or of any other written source. Thus the assumption is tacitly made that evidence from the material culture must have priority over the written evidence, whether biblical or epigraphic. Logically this is fallacious because there is nothing inherent in the material culture which gives it a precedence over the written evidence. To the contrary, each must be given due weight in any historical reconstruction.

Two examples of this fallacy may be found in the area of historical geography. They concern the location and habitation of sites which are epigraphically attested but whose archaeological evidence is not clear. The first has been noted already by Kenneth Kitchen. ${ }^{4}$ It has to do with the location and existence of the Moabite Dibon in the 13th century. The name, $t b n$, was read and published by Kitchen in 1964 in a list of

${ }^{4} \mathrm{~K}$.A. Kitchen, 'The Egyptian Evidence on Ancient Jordan', in P. Bienkowski (ed.), Early Edom and Moab. The Beginning of the Iron Age in Southern Jordan (Sheffield Archaeological Monographs 7; Sheffield: J.R. Collis, 1992) 21-34, especially 27-29. 
Transjordanian conquests claimed by Ramsses II. 5 Unfortunately, excavation of the site identified with biblical Dibon has yielded no remains from the Late Bronze Age or the Early Iron Age. ${ }^{6}$ There has been a spate of attempts to deny this reading and its equation with Dibon, a site attested in the Transjordanian wanderings of early Israel (Nu. 21:21-31; Jos. 13:15-23). ${ }^{7}$ Indeed, in a recent study on early Israel, W. Dever uses the absence of archaeological evidence from Dibon as a parade example to demonstrate his argument for the lack of historical reality in the relevant biblical accounts: ${ }^{8}$

In Transjordan, the same is true; sites like Hesbon (biblical Heshbon), Dibhan (biblical Dibon) and others that are mentioned in the biblical accounts were not occupied in the late 13 th or early 12 th century B.C.E., so they cannot have been destroyed. Archaeology can rarely prove something in the affirmative, but it can often prove things in the negative. It can prove that such and such did not happen, and could not have happened. That's the case here, because the archaeological record is totally silent.

However, Dibon did exist and was known to the scribes of Ramsses II. Whether it was at the site traditionally identified with Dibon or elsewhere in the region of Moab, the Egyptian record demonstrates the fallacy of assigning a priority to the archaeological evidence in this case. Kitchen comments: 9

5Idem, 'Some New Light on the Asiatic Wars of Ramesses II', JEA 50 (1964) 47-70.

6A.D. Tushingham, 'Dibon', D.N. Freedman et al. (eds.), The Anchor Bible Dictionary. (New York: Doubleday, 1992) Vol. 2, 194-196.

${ }^{7}$ Kitchen, 'The Egyptian Evidence on Ancient Jordan', 28-29.

8 W.G. Dever, 'How to Tell a Canaanite from an Israelite', in H. Shanks et al. (eds.), The Rise of Ancient Israel. Symposium at the Smithsonian Institution October 26, 1991 (Washington, DC: Biblical Archaeology Society, 1992) 26-60, especially 32.

9'The Egyptian Evidence on Ancient Jordan', 28-29. Cf. similar comments by G.W. Ahlström, The History of Ancient Palestine from the Palaeolithic Period to Alexander's Conquest (JSOTS 146; Sheffield: Sheffield Academic Press, 1993) 410, n. 2. Strangely, this does not prevent Ahlström from arguing for the non-existence of an Iron Age Dibon on pp. 415-416, where he uses the same absence of archaeological evidence as his basis. 
Our knowledge of the main mound at Dhiban is incomplete -and there is no guarantee that the Late Bronze settlement was on that spot, rather than nearby, whether under the modern village or elsewhere. Site-shift is so well attested a phenomenon that it cannot be arbitrarily ruled out here. The Egyptian texts in this matter are valuable evidence hinting at what we have so far missed, and should not be cavalierly dismissed...

A second example is also attested in Ancient Near Eastern and biblical sources such as Joshua and Judges, or at least this was thought to be the case. The site is the well-known city of Jerusalem. In a recent article Franken and Steiner have argued that the Jebusite evidence which Dame Kathleen Kenyon identified at the City of David should now be redated to after 1200.10 They conclude that the site was uninhabited during the Late Bronze Age. Traditionally, the ú-ru-sa-lim of the Amarna letters has been identified with Jerusalem. Franken and Steiner imply that this identification can no longer be accepted, but that Amarna ú-ru-sa-lim should be located north of Palestine in Syria. Of course, this implies that none of the accounts in Joshua 10 and Judges 1:21, which mention Jerusalem, can reflect any realities from the Late Bronze Age, as may be implied by the contexts in which these biblical narratives are found.

Setting aside the question of whether or not archaeological evidence from the Late Bronze Age has been found at the City of David, I wish instead to consider the location of u-ru-sa-lim as suggested by the Amarna letters. ${ }^{11}$ The question to be asked is where it must be located given the

10H.J. Franken and M.L. Steiner, 'Urusalim and Jebus', ZAW 104 (1992) 110-111.

${ }^{11}$ Concerning the question of archaeological evidence for Late Bronze Age and Early Iron Age occupation at Jerusalem, see M.L. Steiner, 'The Jebusite Ramp of Jerusalem: The Evidence from the Macalister, Kenyon and Shiloh Excavations', = A. Biran and J. Aviram (eds.), Biblical Archaeology Today, 1990. Proceedings of the Second International Congress on Biblical Archaeology. Jerusalem, June-July 1990 (Jerusalem: Israel Exploration Society, 1993) 585-588. Cf. also the response of J.M. Cahill and D. Tarler, ibid., 625-626, and the discussion of A. Ofer, ibid., 628-629. 
contexts of the name in the letters in which it appears. ú-ru-salim appears in three Amarna letters, all written by IR- he-ba, the ruler of the city. ${ }^{12}$ This ruler is mentioned by Shuwardata, leader of Gath, in the context of leaders of Shechem, Keilah, Acco and Achshaph. ${ }^{13}$ In his own letters, IR- he-ba mentions Gezer, Ashkelon, Lachish, Ayyalon, and perhaps Beth Horon as regions which are to be located near ú-ru-sa-lim .14 All of these towns and cities suggest that the $u^{-}-r u-s a-l i m$ of the Amarna letters is best located at or near the later city of Jerusalem. The associations mentioned do not allow for a location in Syria to the north of Palestine. Again, the written evidence has a priority insofar as the existence of the site is concerned. Whether or not archaeological attestation has been found for Late Bronze Age Jerusalem at the City of David, the extrabiblical (as well as biblical) written evidence attests to its location in this region. 15

Therefore, it is a fallacy to assume that the material culture has a logical and necessary priority over the written evidence. ${ }^{16}$ Each must be interpreted in its own context and allowed to inform the other. The particular weight given to written sources depends upon a variety of factors which cannot be predetermined by generalisations about the importance of the archaeological evidence.

\section{Canaanite $=$ Israelite}

Fallacies in the interpretation of the culture of early Israel are closely tied to archaeological assumptions about ethnicity and

12EA $287.25,46,61,63 ; 289.14,29 ; 290.15$. The standard translation of all the Amarna letters is now W.L. Moran, The Amarna Letters (Baltimore: Johns Hopkins UP, 1992). See also R.S. Hess, Amarna Proper Names, Ph.D. dissertation, Hebrew Union College (Winona Lake: University Microfilms, 1984) 496.

${ }^{13}$ See EA 280 and 366, both letters by Shuwardata.

${ }^{14}$ The identification of Beth Horon in EA 290 is made by Z. Kallai and H. Tadmor, 'Bit Ninurta $=$ Beth Horon-On the Origin of the Kingdom of Jerusalem in the Amarna Period', EI 9 (1969) 138-147 (Hebrew).

${ }^{15} \mathrm{Cf}$. N. Na'aman, 'Canaanite Jerusalem and Its Central Hill Country Neighbours in the Second Millennium B.C.E.', UF 23 (1992) 275-291.

${ }^{16}$ Cf. W.G. Dever, 'Biblical Archaeology: Death and Rebirth', in Biran and Aviram (eds.), Biblical Archaeology Today, 1990, 706-722, especially 712. 
its attestations in the text. The foremost example of this is the equation of Israelites with Canaanites. ${ }^{17}$ This view assumes that the two groups were one and the same in the Late Bronze Age. It is based on the archaeological conclusion that there is nothing distinctive about the hill country culture of Iron Age I in comparison with the preceding Late Bronze Age. Dever uses a characteristically vivid description of this conclusion: 18

In short, if you had been walking in the countryside of central Palestine, especially in the hill country, in the 12th or 11th century B.C.E. and had met several people, you could probably not have distinguished Israelites from Canaanites or Canaanites from Philistines. They probably looked alike and dressed alike and spoke alike. But the kinds of things that now enable us to talk about ethnicity will have disappeared from the archaeological record.

Thompson would carry these conclusions farther. Concerned to demonstrate that the transition from the Late Bronze Age to the Early Iron Age was one caused by increasing drought and the effects of shortages within the land, he is reluctant to find in the hill country settlements of this period evidence of any migrations from outside, and he is much less inclined to assign them to any entity such as Israel. Rather, he sees it as the continuation of a process already begun in the Late Bronze Age and reflecting subsistence strategies among native Palestinians. ${ }^{19}$

Three issues emerge which the textual sources address in a substantial fashion: (1) the equation of Israelite ethnicity with that of the indigenous inhabitants of the land; (2) the nature of early Israelite religion; and (3) the extent to which

17This term is used despite the attempt to disavow any equation of biblical Canaanite with the inhabitants of the land which sources from Egypt and from the land itself identify as Canaan. Cf. N.P. Lemche, The Canaanites and Their Land: The Tradition of the Canaanites (JSOTS 110; Sheffield: Sheffield Academic Press, 1991); Thompson, Early History of the Israelite People, 167-168; and my review of Lemche, Themelios 18/2 (January 1993) 24.

${ }^{18}{ }^{\prime}$ How to Tell a Canaanite from an Israelite', 54.

${ }^{19}$ Early History of the Israelite People, 304-305. 
Late Bronze Age Palestine (especially the hill country) was cut off from international contacts and peoples.

The first question includes one point which is not disputed. It is difficult to establish ethnicity. Indeed, ethnicity often is impossible to determine from material culture because this reflects the challenges of the environment and coping strategies, rather than one particular lineage as opposed to another. Nor is it clear that there is any difference in the biblical memory of early Israel. To the contrary, the written evidence indicates that Israelites were determined to make themselves indistinguishable from the other inhabitants of the hill country. This is explicit in Judges 3:5-6 (NIV):

The Israelites lived among the Canaanites, Hittites, Amorites, Perizzites, Hivites and Jebusites. They took their daughters in marriage and gave their own daughters to their sons, and served their gods.

Thus even in religious matters, which lay at the heart of Israelite culture (as they do of most ancient cultures), most Israelites could not be distinguished from their neighbours.

However, there is another aspect to Israelite and Canaanite religious practices. This has to do with the public declaration of the religion which the Israelites practised. An important source of information regarding religion can be found in the personal names which Israelites and other groups gave to their offspring. Theophoric elements, and especially divine names, which formed part of the personal names, provide valuable insight into the religious culture of a people. Although the analysis of such names does not allow a simple correspondence with the religious beliefs of the name bearers, it does shed some light on the public aspects of a people's religious convictions.

For example, the almost exclusively Yahwistic nature of Israelite and especially Judean personal names during the 1st millennium suggests something about the public confession of the name bearers as adherents to the worship of Yahweh.20

20J.H. Tigay, You Shall Have No Other Gods: Israelite Religion in the Light of Hebrew Inscriptions (Harvard Semitic Series 31; Atlanta: 
Between the 8th century and the fall of Jerusalem, less than six per cent of the personal names which Tigay collected from extrabiblical sources include divine names other than Yahweh or the generic El.21 The number is slightly less for the biblical names of the same period, even if one counts all $b^{c} l$ and $\check{s} d y$ names as non-Yahwistic. 22 de Moor's analysis of names which the Bible locates in the pre-Davidic period yields a higher percentage of divine names other than Yahweh or El, but it is still a minority at 21 per cent. ${ }^{23}$ The most popular divine name of this period was El. We may conclude that, although the period of early Israel was one characterised by involvement in non-Israelite cultic practices, the religious sentiment of the people remained such that Yahweh and El were the chief divine names used by the Israelites of that age. Indeed, it may

Scholars, 1986); idem, 'Israelite Religion: The Onomastic and Epigraphic Evidence', in P.D. Miller, Jr., P.D. Hanson, and S.D. McBride (eds.), Ancient Israelite Religion: Essays in Honor of Frank Moore Cross (Philadelphia: Fortress, 1987) 157-194; A.R. Millard, review of Tigay, You Shall Have No Other Gods, IEJ 41 (1991) 224-226. The distinctive nature of the theophoric evidence is also studied in detail by G.B. Gray, Studies in Hebrew Proper Names (London: A. \& C. Black, 1896); M. Noth, Die israelitischen Personennamen im Rahmen der gemeinsemitischen Namengebung (Stuttgart, 1928; repr. Hildesheim: G. Olms, 1966); J.D. Fowler, Theophoric Personal Names in Ancient Hebrew: A Comparative Study (JSOTS 49; Sheffield: Sheffield Academic Press, 1988); R. Zadok, The Pre-Hellenistic Israelite Anthroponymy and Prosopography (OLA 28 Leuven: Peeters, 1988). Important observations regarding the limitations of onomastic study for determining the religious beliefs of the name bearers may be found in D. Pardee, 'An Evaluation of the Proper Names from Ebla from a West Semitic Perspective: Pantheon Distribution according to Genre', in A. Archi (ed.), Eblaite Personal Names and Semitic Name-Giving: Papers of a Symposium Held in Rome July 15-17, 1985 (Archivi Reali de Ebla Studi 1; Rome: Missione Archeologica Italiana in Siria, 1988) 119-151; J.J.M. Roberts, review of Fowler, Theophoric Personal Names in Ancient Hebrew, JBL 109 (1990) 316-317.

21 Tigay, You Shall Have No Other Gods, 9-17.

22See J.C. de Moor, The Rise of Yahwism: The Roots of Israelite Monotheism (Bibliotheca Ephemeridum Theologicarum Lovaniensium 91; Leuven: Peeters, 1990) 30, summarising the evidence collected by J.D. Fowler, Theophoric Personal Names in Ancient Hebrew.

${ }^{23}$ The Rise of Yahwism, 33. 
be that an 11th century B.C. arrowhead has been identified which contains an example of the earliest extrabiblical attestation of a Yahwistic name. ${ }^{24}$ Although the original provenance of the artefact is unknown, the discovery of similar arrowheads in a cave near Bethlehem suggests the possibility that this one may also originate in Palestine. This evidence, if it proves to be authentic, further supports the presence of Yahwistic names in Palestine in the Israelite period. The Bible consistently associates such names with Israelites.

Elsewhere in the West Semitic world of the Late Bronze Age, such as in sites north of Palestine, religious beliefs and rituals are well attested by cuneiform archives. However, in Palestine this is not the case. Instead, the one substantial collection of written records from the Late Bronze Age, the Amarna letters, contains little information about the beliefs and practices of people in Palestine. ${ }^{25}$ In contrast, an examination of the divine elements within the personal names of city leaders and others from Palestine yields a rich and varied harvest of gods and goddesses. Besides Indian, Egyptian, and Hurrian deities, there are numerous West Semitic deities, including Addu, Ammu, Anat, Asherah, Astarte, Baclu, Dagan, El, Milku, Ram, Tirši, Tsaduq, and Yam. ${ }^{26} \mathrm{El}$ appears in ten names, which is fewer than either Addu or Ba'lu. $\mathrm{El}$ is in a minority, though as a generic name for any deity, it is not clear that the frequency of occurrences of this name is significant. Yahweh is not mentioned at all. ${ }^{27}$

24F.M. Cross, 'An Inscribed Arrowhead of the Eleventh Century BCE in the Bible Lands Museum in Jerusalem', EI 23 (1992) 21*-26*, especially $21^{*}$. Provisionally, Cross reads the name as $y w h n n$, presumably with the meaning, 'Yahweh is gracious.'

${ }^{25}$ See R.S. Hess, 'Divine Names in the Amarna Correspondence', UF 18 (1986) 149-168, especially 162-163; N. Na'aman, 'On Gods and Scribal Traditions in the Amarna Letters', UF 22 (1990) 247-255.

26See R.S. Hess, Amarna Personal Names (ASOR Dissertation Series 9; Winona Lake: Eisenbrauns, 1993) 233-242; W.L. Moran, The Amarna Letters (Baltimore: Johns Hopkins UP, 1992) 386-388.

${ }^{27}$ For criticism of an attempt to identify a Yahwistic personal name in the Amarna letters from Tyre, see R.S. Hess, 'Personal Names from Amarna: Alternative Readings and Interpretations', UF 17 (1985) 157167; idem, 'References to the Divine Name Yahweh in Late Bronze Age Sources?', UF 23 (1991) 181-188. 
Thus a cultural distinction is identifiable in the personal names of the Late Bronze Age inhabitants of Palestine as opposed to those who appear and are associated with Israel in the biblical tradition. If we are prepared to accept the antiquity of the personal names found in biblical narratives which describe events before the time of the Israelite Monarchy, then one cannot claim that no feature distinguished Israelites from their neighbours. 28

No less significant than the problem of distinguishing Israelites from their neighbours is the question of the extent to which Palestine of the Late Bronze Age was a closed society. As noted above, Thompson holds to the view that there was minimal influence from outside during this period. Again, the Amarna texts preserve evidence of cultural influence and of the penetration of the region by immigrants from outside the land. This influence is evident from the north, from the Late Bronze Age empires of the Hittites and of the Hurrians. There are two lines of evidence which the texts provide, the evidence of northern influence in the writing style of certain scribes and once again the personal names.

The Amarna texts from Palestine are written in dialects which are part of a group associated with Western Akkadian. Although Akkadian is attested in contemporary Syria and Mesopotamia, its occurrence in Palestine is not in itself evidence for influence from these regions. As the discovery of the texts at the Egyptian New Kingdom capital, today known as Amarna, demonstrates, this was the international script and language of the Late Bronze Age. Therefore, the use of the Akkadian language by scribes in Palestinian towns which were under the control of the Egyptian empire should not be a surprise.

${ }^{28}$ Even as sceptical a critic as Thompson would allow for some antiquity to genealogical records in the Bible. See Thompson, Early History of the Israelite People, 366, though with cautions that this cannot be understood or evaluated without a historical context. For the early date of personal names elsewhere in the biblical texts, see the ascription of the names of Genesis 1-11 to a West Semitic context in the early 2nd millennium B.C. in R.S. Hess, Studies in the Personal Names of Genesis 1-11 (Alter Orient und Altes Testament 234; Kevelaer: Butzon \& Bercker; Neukirchen-Vluyn: Neukirchener, 1993). 
There is a distinction in the syntax of letters written from the region south of Tyre, Beirut, and Amurru in comparison with letters written from regions north of these states. This seems to be the case in the word order of verbal clauses, which follow the standard order in the north, where the verb appears at the end of the clause. ${ }^{29}$ In the south, however, the verb more often appears at the beginning of the clause. A similar distinction has been noted regarding case vowels on personal names. ${ }^{30}$ South of Tyre and Amurru case vowels on personal names can operate on a triptotic declension system. From Tyre and north, case vowels are not used on personal names, with the exception of Byblos. Thus there is a distinction between Palestine and regions to the north.

This might seem to support the suggestion that Palestine was isolated. However, there is an important exception, Jerusalem. Jerusalem, unlike its Palestinian neighbours, does not always use case vowels in personal names which can operate with such vowels. In addition, there are scribal peculiarities which are most closely related to letters north of the dialectical border. ${ }^{31}$ Therefore, it would appear that there has been scribal influence from the north in Jerusalem. This can best be explained by cultural influence and the migration of a scribe or, more likely, of the leader's family who were the actual authors behind this correspondence. The evidence points to more than influence. It points to movement from the north.

${ }^{29}$ T.J. Finley, Word Order in the Clause Structure of Syrian Akkadian, Ph.D. dissertation, University of California at Los Angeles (Ann Arbor: University Microfilms, 1979).

${ }^{30}$ R.S. Hess, 'The Operation of Case Vowels in the Personal Names of the Amarna Texts', Mesopotamie et Elam: Actes de la xxxvième rencontre assyriologique internationale Gand, 10-14 juillet 1989 (Mesopotamian History and Environment Occasional Publications 1, Ghent, 1991) 201-210.

${ }^{31}$ W.L. Moran, 'The Syrian Scribe of the Jerusalem Amarna Letters', in H. Goedicke and J.J.M. Roberts (eds.), Unity and Diversity (Baltimore: Johns Hopkins UP, 1975) 146-166. 
The second source of evidence comes from the personal names of leaders and other figures mentioned in the Amarna letters. Thompson is aware of this source and comments: 32

The onomastics of the Late Bronze period also suggest at least some very minimal influx or influence of peoples from Hurrian and Hittite regions, but even names do not imply ethnicity.

In fact the evidence from the personal names is substantial. The relevant etymologies for the personal names can be located either in the West Semitic language family or in the northern influence, represented by Hurrian, Indo-Aryan, and Anatolian language families. West Semitic names do not suggest influence from outside Palestine. Northern names do suggest such influence. When the personal names of the Amarna letters are analysed according to etymology and then plotted on a map according to the city or region with which they are associated, the following results obtain. ${ }^{33}$ West Semitic names dominate the Mediterranean coast. From the Lebanese Biqa Valley reaching south into the Damascus and Golan regions, there is a predominance of northern names, although both Hazor and Pella seem to be dominated by leaders with West Semitic names. The coastal plain and the Shephelah have a preponderance of West Semitic names. The Jezreel Valley and the hill country include towns whose leaders possess both West Semitic and northern names.

These results indicate that the influence of northern culture is strongest inland in the valleys and in the adjacent hill country of Palestine. This onomastic evidence corresponds

${ }^{32}$ Early History of the Israelite People, 305. Cf. N.P. Lemche, 'The Old Testament-A Hellenistic Book?' Scandinavian Journal of the Old Testament 7 (1993) 163-193.

${ }^{33}$ W. Helck, Die Beziehungen Ägyptens zu Vorderasien im 3. und 2. Jahrtausend $v$. Chr., Ägyptologische Abhandlungen, Vol. 5 (2nd edition; Wiesbaden: Harrassowitz, 1971) 478-482; W.F. Albright, 'The Amarna Letters from Palestine', in I.E.S. Edwards et al. (eds.), The Cambridge Ancient History, Vol. II.2 (3rd edition; Cambridge: CUP, 1975) 98-116; R.S. Hess, 'Cultural Aspects of Onomastic Distribution in the Amarna Texts', UF 21 (1989) 209-216. 
precisely to the archaeological evidence. ${ }^{34}$ While Thompson is correct that the etymologies of personal names cannot determine ethnicity, the number of names and the geographical extent of the survey suggest that the inland regions were in regular contact with the north and that the dynasties in various towns may have had their origin in the north.

\section{Conclusion}

I have argued that the following are fallacies: 1 . the material culture has a logical and necessary priority over the written evidence; 2 . there was a minimal influx or influence of peoples and their culture from outside Palestine in the Late Bronze Age. Both of these conclusions have relevance for the use of the Bible in the recovery of the history of early Israel. First, the biblical witness, like other epigraphic evidence, must be assessed on its own merit. It cannot be excluded automatically where evidence from the material culture does not appear to agree with it. Second, however much there is evidence for a continuity of material culture from 'Canaanite' to 'Israelite' strata at Palestinian sites, the possibility of cultural influence and migration from outside the country cannot be excluded. The Palestinian hill country was not an 'insulated island', sealed off from contacts with the north or with the south. Thus the biblical witness of an Israelite 'entrance' into Canaan from outside is consistent with textual evidence from the Late Bronze Age.

The following observations may be offered in conclusion: First, the fallacies identified here reflect the shifting emphases as the old models of interpretation prove inadequate and there is a need for new approaches. This may suggest a paradigm shift, but what is presently happening is not a shift toward a particular model as much as an awareness of the variety of possible models available for the interpretation of early Israel. These models differ according to

${ }^{34}$ See the bibliography in Hess, 'Cultural Aspects of Onomastic Distribution', 214-215. 
the emphasis placed upon the mass of written, archaeological and ecological data available to the historian.

Second, it is not correct methodology to ignore the written evidence and its importance in the pursuit of alternative methods of explanation. Such evidence can demonstrate the existence of places not yet discovered by archaeology. It can also suggest the presence of migration and cultural influence which can balance the conclusions drawn from other methods which focus on internal changes within a land.

Third, biblical and other records describe the period under consideration as including a recognisable Israel. Epigraphic evidence suggests that Israelites preserved their identity in the biblical literature without compromising their description of the historical period in which they came into existence. 